\title{
'In aliquibus locis est consuetudo': French Lawyers and the Lombard Customs of Fiefs in the Mid-Thirteenth Century
}

\author{
ATTILIO STELLA
}

The long-standing problem of the authority of custom has concerned generations of legal historians, and its development in the twelfth and thirteenth centuries has occupied a privileged seat in this debate. ${ }^{1}$ This period was indeed a highly constructive one, being at the intersection of a series of processes which would lead to a wealthier, more populated and better-organised society and thus lay the foundations of modern Europe. The emergence of the ius commune and its relations with local legal traditions consequently lie at the core of various paradigms concerning the history of Continental law and European legal systems. Studies on the legal and institutional processes of this period have shed much light upon the revival of Roman law, the new ways of conceiving of law and the legal profession, as well as the progressive bureaucratisation of power relationships and an ever more widespread commitment of law to writing. ${ }^{2}$ In this essay, I consider one of the most powerful among the narratives that have informed historical interpretations of this age of change. It became

${ }^{1}$ V. Scialoja, 'Sulla const. 3 Cod. Quae sit longa consuetudo e la sua conciliazione col fr. 32, $\$ 1$, Dig. De legibus: difesa di un'antica opinione', Archivio giuridico, 24 (1880), 420-30; E. Cortese, La norma giuridica. Spunti teorici nel diritto comune classico, 2 vols. (Milan, repr. 1995), vol. II, 101-67; A. Gouron, 'Coutume contre Loi chez les premiers glossateurs', in A. Gouron and A. Rigaudiére (eds.), Renaissance du pouvoir législatif et génese de l'Etat (Montpellier, 1988), 117-30; E. Conte, 'Roman Law vs Custom in a Changing Society: Italy in the Twelfth and Thirteenth Centuries', in P. Andersen and M. Münster-Swendsen (eds.), Custom: The Development and Use of a Legal Concept in the Middle Ages (Copenhagen, 2009), 33-50.

${ }^{2}$ H. J. Berman, Law and Revolution: The Formation of the Western Legal Tradition (Cambridge, 1983), 120-64; M. Bellomo, The Common Legal Past of Europe, 1000-1800 (Washington, DC, 1995); S. Reynolds, 'The Emergence of Professional Law in the Long Twelfth Century', Law and History Review, 21(2) (2003), 347-66. 
widespread in modern scholarship thanks to the influence of the nineteenth-century German constitutionalists, who envisaged this period as a transition from an age dominated by customary law to an age governed by the new law of the 'learned. ${ }^{3}$ Following old anti-Romanist sentiments - the first examples date to sixteenth-century France - this view found one of its most prominent supporters in Fritz Kern. In an influential article on law and constitution in the Middle Ages (1919), then translated into English in his book Kingship and Law (1939), the German scholar deemed custom to be the only true law of medieval people. ${ }^{4}$ Resting on habit (Sitte) and popular belief (Volksglaube), custom was 'warm-blooded, vague, confused, and impractical, technically clumsy, but creative, sublime, and suited to human needs'. At the opposite end, Roman law was considered a cold artificial construct, alien to medieval societies, made up of 'unintelligible laws [that] seem to be made arbitrarily by men, or even to be taken over from the heathen Romans, and resurrected at Bologna in lecture-rooms and folio volumes. ${ }^{5}$

The opposition of 'cold new law' against 'warm old custom' seems to owe much to the 'Italophobia' developed by early modern French intellectuals, but this was then reformed into a Romanticised idea of the adherence of custom to the spirit of the nation. ${ }^{6}$ It would be redundant to repeat here the various criticisms brought against this ideological stance. ${ }^{7}$ It is worth noting, however, that the powerful narrative of a clear-cut shift from custom-based societies towards systems based on positive, codified law has been very resilient, carving its way into current historical interpretations of the twelfth- and thirteenth-century transition. It is sufficient merely to glimpse the sheer abundance of legal anthropological studies for the pre-transition era and the predominance

3 Conte, 'Roman Law'; E. Conte, 'Consuetudine, Coutume, Gewohnheit and Ius Commune: An Introduction', Rechtsgeschichte, 24 (2016), 234-43; L. Gilissen, La coutume (Turnhout, 1982), 24-32.

${ }^{4}$ F. Kern, 'Recht und Verfassung im Mittelalter', Historische Zeitschrift, 120 (1919), 1-79, translated into English as F. Kern, Kingship and Law in the Middle Ages: A Classic Study of Early Constitutional Law, trans. S. B. Chrimes (Oxford, 1939).

${ }^{5}$ Kern, Kingship, 179-80.

${ }^{6}$ D. R. Kelley, 'De Origine Feudorum: The Beginnings of an Historical Problem', Speculum, 39(2) (1964), 207-28, at 207-8.

7 Andersen and Münster-Swendsen (eds.), Custom; M. Ryan, 'Feudal Obligations and Rights of Resistance', in N. Fryde, P. Monnet, and O. G. Oexle (eds.), Die Gegenwart des Feudalismus (Göttingen, 2002), 51-78. 
of rigorously legal studies for the post-transition period in order to understand how historians still tend to assume the model implicitly. ${ }^{8}$

\section{From the 'Feudal Law' of the Medieval State to the Rediscovery of the Libri feudorum}

The study of feudal law emerging in the twelfth and thirteenth centuries represents a privileged vantage point to reappraise this transition since it lies at the core of old and recent debates on the relationship between law and custom. Our point of departure will be the paradigm of feudalism developed by François-Louis Ganshof, one of the most resilient legal interpretations of feudal relationships. In his most famous book, Qu'est-ce-que la féodalité? (1944), Ganshof relied on the foundational idea that feudal law was the law of the medieval state par excellence. An earlier formulation of this idea was proposed by the German historian Heinrich Mitteis, who, in his book Lehnsrecht und Staatsgewalt (Feudal Law and State Power, 1933), framed within a coherent constitutional theory the shared conviction that feudalism had first emerged in the Merovingian and Carolingian eras. In Mitteis's and Ganshofs view, feudal law was a very apt example of law emerging from raw practice, in a way that in many aspects matched the constitutionalist idea of custom. Feudal law, indeed, was thought to stem naturally from the power relationships that kept the nobility together in the heartland of the Carolingian empire. Here, feudal relationships were nothing more than private agreements between lords and their followers. The Carolingians, however, created a constitutional precedent by using them as vital tools for the creation of imperial authority. The progressive formalisation of the rules governing the exchange of fiefs and protection in return for fidelity and military aid, sealed through precise rituals, would develop only later, from the tenth to the thirteenth centuries, the age of classic feudalism. Concerned as they were with suggesting a coherent model potentially applicable to all of medieval Europe, Mitteis first and Ganshof afterwards proposed that

${ }^{8}$ W. Davies and P. Fouracre (eds.), The Settlement of Disputes in Early Medieval Europe (Cambridge, 1992); C. Wickham, Courts and Conflict in Twelfth-Century Tuscany (New York, 2003); F. Cheyette, 'Suum cuique tribuere', French Historical Studies, 6(3) (1976), 287-99. Criticisms of this methodological divide come from: S. Teuscher, Lords' Rights and Peasant Stories: Writing and the Formation of Tradition in the Later Middle Ages (Philadelphia, PA, 2012); B. Lemesle, Conflits et justice au Moyen Âge. Normes, loi et résolution des conflits en Anjou au XIe et XIIe siècles (Paris, 2008). 
the feudal law developing from the Carolingian era was the only possible means by which any medieval form of territorial power could guarantee constitutional order and become a state. ${ }^{9}$

The main criticisms brought against this model concern the conviction that feudal law was a spontaneous phenomenon inherent to medieval values - i.e. that it was the law of a profoundly feudal society. ${ }^{10}$ The main fault of Mitteis and Ganshof was to have neglected in their shaping of the feudal categories the role of a book, the Libri feudorum, that had been compiled in twelfth- and thirteenth-century Italy. ${ }^{11}$ To be sure, the book had been studied almost uninterruptedly for centuries, but most modern scholars had (to some extent rightly) deemed it to be nothing more than the local custom of northern Italy, and hence evidence for the Lombard fief alone. ${ }^{12}$ Nonetheless, the extraordinary afterlife of the Libri deserved a more thorough analysis. In its first version, the book was a compound of early twelfth-century source material on fiefs, written and collected by Lombard practitioners to help other Lombard practitioners. Seven short tracts were first put together about 1150 , but other texts were continuously added for about a century. ${ }^{13}$ By 1207, an incomplete apparatus of glossae was compiled, and, by about 1250, Accursius, the most famous law professor in Bologna, concluded this work. The completion of the apparatus allowed the inclusion, apparently by Accursius himself, of the Libri in the new editions of the Corpus iuris civilis produced in Bologna. The Libri thus became the tenth book of the Authenticum - the collection of

${ }^{9}$ H. Mitteis, Lehnsrecht und Staatsgewalt. Untersuchungen zur mittelalterlichen Verfassungsgeschichte (Weimar, 1933); F.-L. Ganshof, Qu'est-ce-que la féodalité? (Brussels, 1944).

10 See the outline in D. Heirbaut, 'Feudal Law', in H. Pihlajamäki, M. D. Dubber and M. Godfrey (eds.), The Oxford Handbook of European Legal History (Oxford, 2018), 528-48.

${ }^{11}$ LF 1 and LF 2 refer respectively to book 1 and book 2 of the Libri feudorum, edited in K. Lehmann, Das Langobardische Lehnrecht (Handschriften, Textentwicklung, ältester Text u. Vulgattext): Nebst den Capitula Extraordinaria (Göttingen, 1896). All translations of this text are mine.

12 The title of the 1896 edition, 'The Feudal Law of the Lombards' reveals this conviction: Lehmann, Das Langobardische Lehnrecht. The same idea is expounded by the influential Italian author P. Brancoli Busdraghi, La formazione storica del feudo Lombardo come diritto reale (Spoleto, 1999).

${ }^{13}$ P. Weimar, 'Die Handschriften des Liber Feudorum und seiner Glossen', Rivista Internazionale di Diritto Comune, 1 (1990), 31-98. 
Justinian's Novels until then subdivided into nine books. ${ }^{14}$ This insertion, of course, would grant to the book an exceptional and enduring success. The Libri became the reference book to drive doctrinal debate on fiefs in a way that makes it very difficult to doubt its long-term influence in shaping late medieval and modern notions of feudal law and feudalism. This may also make it 'incomprehensible', as Dirk Heirbaut suggests, that views such as Mitteis's and Ganshof's could survive well into the 1990s. ${ }^{15}$

Susan Reynolds, the most radical opponent of the Ganshofian model, holds that the Libri feudorum was probably principally responsible for the construction of a 'feudal vocabulary' through four centuries of scholarly debate on feudal law and feudalism. ${ }^{16}$ Her views have gained considerable authority among medievalists, but have been criticised by historians of medieval law mainly on the grounds that, at least from the twelfth century onwards, more or less formalised norms regulating feudal practices and institutions existed independently of any scholarly interpretation of the Libri. ${ }^{17}$ I argue that holding that the new law - or the new fief - was entirely a product of the professionalisation of law or, more precisely, of the combined action of rulers and their bureaucrats may be seen as bearing the same original sin as the old German constitutional theory of custom vis-à-vis law. It rests on the assumption of a gap between custom accessible by any common man and the merely artificial new law. The relevant question here goes beyond whether the Libri feudorum related to the socio-political developments of twelfthcentury Lombardy - and thus whether the book contained customary law or not. The principal problem, which I am going to tackle, is understanding how some of the 'learned' agents of this process, the alleged makers of the artifice, conceived of the practices and customs of fiefs they described in their treatises, and arguably taught to their students, in relation to the

14 A. Rota, 'L'apparato di Pillio alle Consuetudines feudorum e il ms. 1004 dell'Archivio di Stato di Roma', Studi e memorie per la storia dell'Università di Bologna, 14 (1938), 61-103; Weimar, 'Handschriften'.

${ }^{15}$ Heirbaut, 'Feudal Law'; K. Pennington, 'Feudal Oath of Fidelity and Homage', in K. Pennington and M. Harris Eichbauer (eds.), Law as Profession and Practice in Medieval Europe: Essays in Honor of James A. Brundage (Farnham, 2011), 93-115; M. Ryan, 'Ius commune feudorum in the Thirteenth Century', in A. Romano (ed.), “... colendo iustitiam et iura condendo ..." Federico II legislatore del Regno di Sicilia nell'Europa del Duecento (Rome, 1997), 51-65.

16 S. Reynolds, Fiefs and Vassals: The Medieval Evidence Reinterpreted (Oxford, 1994), 1-74.

17 Pennington, 'Feudal Oath'; Heirbaut, 'Feudal Law'. 
Libri feudorum. Tackling this issue compels us to consider, on the one hand, the possible normative value of the Libri and, on the other, the mechanisms of its absorption in the system of Civil law, that is, the extent to which the making of the ius commune feudorum related to issues emerging from practice. In what follows I try to answer these questions by briefly considering the impact of the Libri in the thirteenth century and its relations with the customary reality of Italy according to two early authors on feudal law: Obertus de Orto and Iacobus de Ardizone. I move then to a broader analysis of the first treatises on fiefs produced by lawyers from beyond the Alps, to reassess the authoritative and normative value of the Libri outside Italy.

\section{The Influence and Impact of the Libri feudorum}

The life and afterlife of the Libri support the thesis of a broad diffusion of the text from the mid-thirteenth century onwards. Towards the end of the twelfth century, the source material collected in Lombardy became the object of scientific analysis by the Civilians, Pillius de Medicina being most likely the first one to use it as a teaching book, in Modena from 1182. This can be inferred from the fact that he produced an apparatus of glossae to the Libri and a Summa feudorum, which is unfortunately lost and is known only thanks to a substantial reworking, most likely carried out by Accursius. ${ }^{18}$ Thus, the Libri is the first and maybe the only example of a medieval custumal to be accepted as an authoritative source - a teaching book, and hence a citable text - in open contravention of the demand by the Bolognese scholars to cite only the Corpus iuris civilis. However, it was only decades later that experts in law continued the tradition initiated by Pillius. The mysterious Symon Vicentinus (d. before 1263) left some glossae, and he is also known for a Liber domini Symonis, likely to be a lost recompilation of the Libri feudorum. He may have used it as a textbook when he taught in Padua, perhaps in $1222-8$, but this hypothesis is purely speculative. ${ }^{19}$ Iacobus de Ardizone

18 E. Cortese, 'Pillio da Medicina', in I. Birocchi, E. Cortese, A. Mattone, and M. N. Miletti (eds.), Dizionario biografico dei giuristi italiani (XII-XX secolo), 2 vols. (Bologna, 2013) (henceforth, DBGI), vol. II, 1587-90; E. Conte, 'Modena 1182: The Origins of a New Paradigm of Ownership. The Interface Between Historical Contingency and the Scholarly Invention of Legal Categories', GLOSSAE. European Journal of Legal History, 15 (2018), $4-18$.

19 E. J. H. Schrage, 'Symon Vicentinus, un docteur très excellent du XIIIe'siècle', Tijdschrift voor Rechtsgeschiedenis, 55 (1987), 297-320. 
and Odofredus produced glossae and recompilations of the Libri and also two famous Summae feudorum based on the book, probably both written in the 1230s. About 1250, or slightly earlier, the Margarita feudorum by Dullius Gambarini, active in Naples, would attest to the need to normalise the practical application of the book. ${ }^{20}$ On the canonistic side, glossae and commentaries on fiefs flourished after the title De feudis (X. 3.20) was inserted in the Compilatio tertia (1210), but canonists relied almost exclusively on Gratian's Decretum, collections of decretals, and imperial decrees. Only with the Summa decretalium by Hostiensis, concluded about 1253, did the Libri appear as an established source in the Canon law literature, even though the commentary on X. 3.20 contained in this treatise was mostly an adaptation of Accursius's reworking of Pillius's short treatise. ${ }^{21}$ In sum, the so-called ius commune feudorum did not emerge until the second half of the thirteenth century. This success was due principally to the fact that the Justinianic sources did not contain any reference to 'fiefs' and 'vassals' and the glossators felt at some point compelled to find an authoritative source relating to these matters. This limitation of the Corpus iuris civilis was a prevalent complaint among the authors on feudal law, and it also served as a justification for the utilisation of the Libri. ${ }^{22}$

Nonetheless, there are at least three good reasons to believe that such general acceptance of the Libri was neither easy nor immediate. In the first place, the book was not part of the ordinary curricula of the law schools but was taught only in extraordinary lectures; consequently, its teaching was not as widespread as one might think. ${ }^{23}$ In the second place, direct citations of the Libri in charters and court proceedings were quite rare, and such evidence emerges only in the late thirteenth century. ${ }^{24}$ Finally, until then, the ranks of commentators on the Libri - no more

20 A. Stella, 'The Liber Ardizonis: Reshaping the Libri feudorum in the Thirteenth Century', Studi Medievali, 58 (2017), 175-227; M. Montorzi, Processi istituzionali: episodi di formalizzazione giuridica ed evenienze d'aggregazione istituzionale attorno ed oltre il feudo: saggi e documenti (Padua, 2005), 135-259.

21 K. Pennington, 'Enrico da Susa, cardinale Ostiense', in DBGI, vol. I, 795-8; M. Ryan, 'The Libri feudorum and the Roman Law', unpublished $\mathrm{PhD}$ thesis, University of Cambridge (1994), 134-220.

${ }^{22}$ Ryan, 'Ius commune feudorum'.

${ }^{23}$ M. Huneke, Iurisprudentia romano-saxonica. Die Glosse zum Sachsenspiegel Lehnrecht und die Anfänge deutscher Rechtswissenschaft (Harassowitz, 2014), 298-9.

${ }^{24}$ See the consilia by Dino del Mugello: Ryan, 'Ius commune feudorum', 56-65; A. Stella, 'Bringing the Feudal Law Back Home: Social Practice and the Law of Fiefs in Italy and Provence (1100-1250)', Journal of Medieval History, 46 (2020), 396-418. 
than fifteen authors - were tiny if compared with the vast legions of commentators on the Corpus iuris civilis. ${ }^{25}$ Therefore, there is enough evidence to argue that although most Italian lawyers accepted the Libri as both an authoritative source to drive scholarly debate on fiefs and a normative text, most non-Italian lawyers struggled to accept its authority and normativity.

This criticism, indeed, would lie at the core of the sixteenth-century Gallican polemics following the controversy concerning the origins of fiefs, in which Charles Dumoulin played the leading role. The debate was sparked by the fifteenth-century philologists, engendering a series of different interpretations of the historical roots of the fief. It was Dumoulin who put an end to it by imposing the idea that the origins of the fief had been in early medieval Gaul. This was an attempt to undermine any interpretation of the Libri feudorum as a text possessing binding force or even scientific value for French lawyers. Indeed, Dumoulin was a strenuous advocate of the absolute power of the French Crown, and most of his intellectual efforts aimed at stressing the independence of French law from any foreign influence. He refused to accept the binding force of the Corpus iuris civilis, although he could not afford to reject its value in terms of legal science. ${ }^{26}$ The Libri, on the other hand, became a much easier target for such a polemical impetus. The book, he thought, should not be considered part of the Corpus as it was the mere creation of private persons, who had no authority to establish any universal custom or law. It was nothing more than the local custom of Lombardy. ${ }^{27}$

The long-standing success of Dumoulin's theories, along with his depiction of them as a break with the whole medieval tradition of the Glossators and Commentators, has obscured the fact that their germs were already growing in the Middle Ages. For instance, in the midfourteenth century, the Auvergnat lawyer Pierre Jame d'Aurillac, then

${ }^{25}$ G. Giordanengo, 'La littérature juridique féodale', in J.-F. Nieus (ed.), Le vassal, le fief et l'écrit (Louvain-la-Neuve, 2007), 11-34, at 11-12.

26 D. R. Kelley, Foundations of Modern Scholarship: Language, Law, and History in the French Renaissance (New York and London, 1970), 151-82.

27 C. Dumoulin, Opera Omnia (Paris, 1612), cols. 12-13; Kelley, 'De Origine'. The terms of this debate were very far from the concerns of the thirteenth-century jurists. Dumoulin and the French legal antiquarians were rejecting the authenticity of the Libri, as well as its authority and validity, in order to claim the authority, in the kingdom of France, of French customary law. 
teaching at Montpellier, accepted the text as a citable source but firmly opposed its binding force. He asserted that

the written customs of the book of fiefs, from top to bottom, ought not to be held at all as far as it concerns us in the entire kingdom of France. They do not bind us in any way and deservedly so, because they have no authority over us and because they are local. Indeed, if a controversy arises over a fief and there is a custom on that matter that is legally prescribed where the controversy takes place, that [custom] ought to be observed. $^{28}$

Several decades before him, the great Orleanais master Jacques de Revigny (d. 1296) had already taken a very similar stance: even if he considered feudal law to be written law, he scarcely mentioned it, even in his quaestiones on fiefs, and, in his Lectura authentici, he did not consider it as the tenth book of the collection, in contradiction to the Bolognese school. ${ }^{29}$ As we will see, similar disagreements emerged at the very outset of the Civilians' discussion on fiefs.

\section{Lombard Custom Recontextualised}

One of the most common objections to the authority of the Libri was its localised nature. Grants of fiefs in exchange for allegiance, political support or service emerged in several regions of Europe, but regional variations could be substantial, so that a fixed set of rules could hardly be applicable universally. ${ }^{30}$ The Libri, of course, reflected the substantive and procedural rules of twelfth-century Lombardy and not the customary law developing in other regions or times. One of its authors, Obertus de Orto, declared that the 'custom of the realm', i.e. the kingdom of Italy, varied according to the 'diverse practices (mores) of different courts and regions'. For this reason, he could describe nothing more than the 'usage (usus) of fiefs that is held in our lands', i.e. the Milanese territory, wherein he was one of the highest political and judicial authorities. ${ }^{31}$

It took the encounter of the Civilians with the Libri to change the nature of the book radically. By the early thirteenth century, many of the customary norms it contained were obsolete even in Milan, where only

28 My translation from Petrus Jacobi de Aureliaco, Aurea practica libellorum (Cologne, 1575), fo. 273 b.

29 L. Waelkens, La théorie de la coutume chez Jacques de Révigny (Leiden, 1984), 176-8.

30 Heirbaut, 'Feudal Law'.

31 LF 2.1. On Obertus: L. Loschiavo, 'Oberto dall'Orto', in DBGI, vol. II, 1448-9. 
some sections of the book would be inserted in the 1216 'book of the customs of Milan' after thorough selection and updates. ${ }^{32}$ As a source for the study - or the creation - of feudal law it served an entirely different purpose, that is, to offer a shared, no matter how inconsistent, set of notions and problems which the Glossators could use to control doctrinal debate about issues that continued to emerge from practice. ${ }^{33}$ This is evident in Ardizone, who in his Summa feudorum quite plainly followed Obertus in acknowledging the highest authority of custom. Obertus, overturning the meaning of a famous rescript by Constantine on the supremacy of law over custom (C. 8.52[53].2) had suggested that in the judgment concerning fiefs, it is common to say what is contrary to our laws: the authority of the Roman laws is not negligible, but they do not extend their force so far as to override usage and practice (LF 2.1)'. This provocative statement worked as a justificatory opening for Obertus's treatment of the Milanese custom of fiefs by contrast with a broader custom of the realm, which remains in the background of Obertus's tracts without ever being revealed in full. Eighty-odd years later, in the first chapters of his Summa, Ardizone developed this argument by suggesting that unwritten custom was of the highest authority, regardless of its crystallisation in a legal text. In what appears to be a vigorous defence of the helpfulness of the Libri, he went on to say that it was necessary and useful to write about the controversies [over fiefs], not because they would not be valid otherwise, since they would obtain the force of the laws even if they remained in [unwritten] custom.... On the contrary, they are written down to be better committed to memory. ${ }^{34}$

Ardizone's treatise is an excellent example of cross-fertilisation among the various bodies of law. Sources of Roman law, Canon law, Lombard law, and even the Statute Book of Verona are used all together to analyse what the author considered the custom of fiefs only partly reflected in the Libri. ${ }^{35}$ In order to expand his arguments, especially when the Libri or other sources were silent on a matter or perceived of as insufficiently detailed, he did not hesitate to bring in the local custom of Verona, his hometown, where he worked as a judge and public officer and, most

${ }^{32}$ Liber consuetudinum Mediolani anni 1216. Nuova edizione interamente rifatta, ed. E. Besta (Milan, 1949), 119-32; H. Keller, 'Die Kodifizierung des mailänder Gewohnheitsrechts von 1216 in ihrem gesellschaftlich-institutionellen Kontext', in Milano e il suo territorio in età comunale (Spoleto, 1999), 145-72.

${ }^{33}$ Ryan, 'Ius commune feudorum', 51-56.

34 My translation from Iacobus de Ardizone, Summa Feudorum (Asti, 1518), fo. 3r.

35 Stella, 'Bringing the Feudal Law'. 
likely, taught law. ${ }^{36}$ This attitude reflects the bestowal of the highest authority upon unwritten custom on the matter of fiefs: the Libri feudorum, in this sense, is a contingent reflection - one of the many possible ones - of a broader, changing body of unwritten law which needed constant update and expansion.

\section{Feudal Law as Case Law? Jean Blanc and the Provençal Practice}

Like with Russian dolls, Obertus's statement on the authority of custom is embedded in Ardizone's, and both are reported almost literally - one might even suggest copied - in the Epitome feudorum by Iohannes Blancus (Jean Blanc) from Marseille. Blanc was a Provençal law expert who, in the 1230s, like many of his colleagues, studied in Italy, more precisely at the studium of Modena, where Pillius's teachings were still very influential. There he learned Roman law and familiarised himself with the Libri; in about 1250 , perhaps slightly later, he was the first to write a treatise on the book outside of Italy. Because of its apparently unambiguous acceptance of the authority of the Libri and its heavy reliance on Ardizone's Summa feudorum, the Epitome has been said to appear like an Italian treatise in all respects. ${ }^{37}$ In this work, Blanc tended to pass over in silence the fact that he was taking more than inspiration from his sources, which in some cases he copied word for word. Nonetheless, his copying entailed selection. Alterations and addition of material reveal that his agreement was only partial. It was not just passive transcription but an active process of appropriation and recontextualisation. When he discussed the authority of custom and the Libri feudorum, he reported, without citing the source, Ardizone's treatment of the opening of Obertus's tract. In this case, the argument is nearly identical: feudal customs were written down because some disputes over fiefs were solved by Roman law, others by Lombard law, the custom of the realm, or unwritten feudal custom. ${ }^{38}$ It is custom

${ }^{36}$ G. M. Varanini and A. Stella, 'Scenari Veronesi per la Summa feudorum di Iacopo di Ardizzone da Broilo', in P. Maffei and G. M. Varanini (eds.), Honos alit artes. Studi per il settantesimo compleanno di Mario Ascheri. La formazione del diritto comune (Florence, 2014), 266-80.

${ }^{37}$ G. Giordanengo, 'Blanc, Jean', in J.-L. Halpérin, J. Krynen, and P. Arabeyre (eds.), Dictionnaire historique des juristes français, $X I I^{e}-X X^{e}$ siècle (Paris, 2015) (henceforth, DHJF), 114; G. Giordanengo, 'Jean Blanc, feudiste de Marseille XIIIe siècle', Annales de la Faculté de droit de l'Université de Bordeaux, 2 (1978), 71-93.

38 J. Blanc, Epitome feudorum (Cologne, 1565), fos. 17-18. 
that approves these unwritten rules and procedures, which do not need to be crystallised into a text to gain authority. The only practical reason for their commitment to writing is their usefulness for lawyers who need to judge similar disputes; in other words, precedents possess, to some extent, legal authority in feudal matters regardless of their oral or written nature.

This attitude towards practice is well reflected in Blanc's Epitome, which, to my knowledge, is the feudal law treatise that mentions the highest number of real cases, the second one being, not surprisingly, Ardizone's Summa. In the text, Blanc's modus operandi appears in full clarity: in several quaestiones, he begins by displaying an argument derived from one of the Libri, Ardizone's treatise or one of his teachers, but often conceals his source. He then develops it by abstracting a principle and sometimes considering its application to real cases that he witnessed or judged, from which he eventually reaches an original conclusion. These cases are not just informative examples but are used, to some extent, to shape new arguments. Blanc reports disputes involving the Templars, the Cistercians, Provençal bishops, barons, and noblemen, which attest to his fieldwork in Provence in a period spanning from 1237 to the $1250 \mathrm{~s} .{ }^{39}$ For instance, the most famous one, the bishop of Apt v. Bertrand de Simiane (1247), is used to develop the old question 'whether jurisdiction adheres with castles'. Following a quaestio by Pillius, Blanc proved that the enfeoffment of the donjon of a castle entailed the concession of the rest of the fortification and, by extension, the jurisdiction over the inhabitants of the surrounding territory. ${ }^{40}$ Another case, opposing the Templars against the canons of Pignans, served to develop this argument further, by upholding the thesis that even after the destruction of a castle the jurisdiction over its former district would remain united. ${ }^{41}$

One of the most insightful examples, however, is the quaestio concerning whether ecclesiastics can hold fiefs. Blanc began his building of the argument from a passage of Ardizone's Summa, which he reported almost verbatim before expanding it in light of a novel case. The Veronese lawyer held that any churchperson could receive fiefs in a personal capacity since LF 2.40 .3 implied that royal fiefs granted to a church ought to revert temporarily to the king should its rector - i.e. the

39 Giordanengo, 'Jean Blanc', 72-79.

${ }^{40}$ Stella, 'Bringing'.

${ }^{41}$ Blanc, Epitome, fos. 542-50. 
bishop or the abbot - commit a wrong. According to Ardizone, the fact that other sources pointed in another direction - i.e. a fief-holder who becomes a cleric ought to lose the fief - would not constitute an impediment, and so he resolved the matter without further analysis. ${ }^{42}$ Blanc, for his part, had several reservations. He copied Ardizone's short treatment again, with no mention of the source - and added that ecclesiastics could theoretically receive a fief as long as the grantor was aware of their clerical status. ${ }^{43}$ However, he saw 'no reason why a cleric should receive a fief from a layperson' because in that case he would be subject to the secular jurisdiction of the grantor and not the ecclesiastical jurisdiction of his primate, as established by four decretals (X. 2.2.12, 5.39.45, 3.50.3, 3.50.6). ${ }^{44}$ The principal point of friction concerned the prohibition on Cistercians holding any secular power, which was expressed in the rule of the order and later confirmed by Alexander III in the decretal Recolentes (X. 3.35.3) ${ }^{45}$ Blanc decided to mention here a case he saw in Provence, of which there is, unfortunately, no other extant evidence. ${ }^{46} \mathrm{He}$ remains silent on many details, but lets us know that, at some point, one party had exhibited a letter by which Innocent III confirmed to the Cistercians of Thoronet the enfeoffment of a castle by the count of Provence. Blanc's doubts concerned the validity of this confirmation. He suggested that this open breach of the Cistercian rule might still be considered lawful as long as it was demonstrated that it benefited the monks without damaging anyone else (C. 1.19.7, Decr. C. 25 q. 2 c. 15). Nonetheless, for this to happen the confirmation should have made clear that it was meant to break a law, i.e. the decretal Recolentes. Since it did not mention the decretal, and since not even the pope could relieve monks from their own rule (X. 3.35.6), he continued:

it seems to me that this confirmation damages rather than benefits the plaintiffs, for it goes against the rule of their Order and may cause the waiver or forfeiture of the privileges of the Cistercian Order. If the

42 Ardizone, Summa, fo. 8ra.

43 The habit of concealing sources in legal writings was not uncommon among the Glossators, but the matter, to my knowledge, has not been treated in full. I consider some examples in Stella, 'Bringing'. See also E. Conte, 'Framing the Feudal Bond: A Chapter in the History of the Ius Commune in Medieval Europe', Tijdschrift voor Rechtsgeschiedenis, 80 (2012), 481-95, at 490-1.

${ }^{44}$ Blanc, Epitome, fo. 98.

45 The decretal implied that some Cistercian monks had forgotten the pristine nature and rule of their institution in coming to possess towns, mills, and churches, to receive oaths of fidelity and homage, and to hold judicial and fiscal authority.

${ }^{46}$ Blanc, Epitome, fos. 100-3. 
Cistercians accepted such things, which are against the statutes of their Order, they would be judged by the law that is common to everyone and not by the [special law] of the Cistercians, as said in the decretal Recolentes. ${ }^{47}$

On this basis, Blanc ends up declaring this confirmation not only void and useless but most likely false, since it was not credible that the papal curia would overlook such a significant matter.

These instances show very clearly how Blanc did not use actual cases to highlight how existing custom or law ought to be applied in court practice. Rather, he saw in them the generative force of practice. Blanc took novel cases as precedents that could serve to expand the horizons of feudal law, encouraging the creation of new principles. Of course, Blanc was using the interpretative tools provided by the rising ius commune, which entailed a high degree of abstraction and often induced him to conceal his sources or pass over in silence essential details of the cases he took as precedents. But he intended to move seamlessly in the wake of Obertus and Ardizone. The example of Blanc ultimately suggests that the mechanisms of the 'Romanisation' of the fief entailed a process of abstraction that obscures the connections of the 'new' law with practice more to us than to thirteenth-century lawyers.

\section{Jean de Blanot and the Authority of Local Custom}

Blanc had considered the Libri not only as an authoritative source for doctrinal uses but also as a text reflecting custom that needed constant expansion and updates in light of novel cases. Jean de Blanot took a very different stance. Blanot was born in Mâcon (Burgundy) before 1230 to a tax collector of Cluny Abbey. He completed his studies in utroque iure at Bologna, attending the lectures of Odofredus, and he taught in the same university in the 1250s. Later back in Burgundy, he served Duke Hugh IV (d. 1272) and, in exchange for his service, received the castellany of Uxelles as a fief in $1263 .^{48}$ Blanot published his most famous treatise, a commentary upon the title De actionibus of Justinian's Institutes, at the time of his Bolognese teaching. There is no reason to doubt that he wrote it in Italy, but it is nevertheless clear that he had the Burgundian context in mind and, most likely, a Burgundian audience. Emanuele

47 Ibid., fo. 103.

48 P. Arabeyre, 'Blanot, Jean de', in DHJF, 115-17. Although he was bailiff of Charles d'Anjou in 1275-7, his career developed almost exclusively in Burgundy, at the service of Hugh IV and, after him, his son Robert II. 
Conte has noted how the aim of this treatise was 'to cast the social and customary reality of his age in the abstract categories offered by Roman law' and 'to teach practitioners in his homeland how to fit the real relationships prevailing in that region of Europe to the procedural patterns described by Roman institutions'. ${ }^{49}$

A point of particular interest is that Blanot decided to discuss homage and the nature of the feudal bond within a broader treatment of the actio praeiudicialis in rem. In Roman law this actio allowed owners to retrieve the service of their freed slaves (liberti). Blanot implied that the act of homage creating the feudal bond was somehow analogous to the act of manumission of a slave - i.e. it generated similar duties connected to the personal status created by the act. ${ }^{50}$ To be sure, these notions were not entirely new. The analogy between vassals and liberti had already been suggested by Iohannes Bassianus (d. 1197) and Ardizone. ${ }^{51}$ By 1233, Roffredus Beneventanus had discussed the opportunity for lords to use the actio praeiudicialis in the same terms as Blanot did. ${ }^{52}$ However, the chapters on homage, overlordship, and lèse-majesté that the Burgundian lawyer decided to insert in his treatise on legal actions would enjoy an independent and very successful afterlife, being a valuable source for Guillaume Durand's famous Speculum iudiciale and Pere Albert's Customs of Catalonia Between Lords and Vassals. ${ }^{53}$

The point to stress here is that when relying on examples relating to his homeland, Blanot chose to resort to famous historical events, unlike Blanc in his Epitome, which rested on specific court cases attended by the author. Blanot's treatment of lèse-majesté was inspired by the war the French Crown waged against the count of Toulouse (1209-29) and rested on a quaestio - whether the man of my man is my man - already developed by his master Odofredus in similar terms. ${ }^{54}$ Other arguments on overlordship are built on the examples of the 1203 war between

${ }^{49}$ Conte, 'Framing', 486.

50 Ibid., 487.

51 Ardizone, Summa, fo. 9ra: 'Habita similitudine de liberto cui possunt imponi operae tam certae quam incertae ... Nam dominus Iohannes Baxianus` ait quod ea quae in legibus leguntur de libertis etiam a vasallis ex regni consuetudine sunt servanda, et hoc in summa Quibus modis quis possit ab ecclesia repellere in nomine Domini Iesu Christi'.

52 Roffredus Beneventanus, Tractatus iudiciarii ordinis (Cologne 1591), fos. 166ra-170rb.

${ }^{53}$ Conte, 'Framing', 490-1.

54 J. Acher, 'Notes sur le droit savant au moyen age', Revue historique de droit français et étranger, 30 (1906), 138-78, at 160-1 (Ch. XIII); Odofredus Denari, Summa feudorum (Alcalá de Henares, 1584), fo. 112r. 
Burgundy and Lorraine (ch. XIV) and the paradoxical situation in which the king of France found himself when he inherited the county of Mâcon in 1239, being at once overlord and vassal of the bishop of Mâcon (ch. XV). ${ }^{55}$ Blanot's reliance on historical situations and informative examples has been deemed to be an obstacle to our understanding of how practice or local custom shaped his theoretical building. ${ }^{56}$ However, I believe that a closer look into the text proves the contrary.

One must first note that the history of Blanot's chapters on homage is quite problematic. One fourteenth-century code, in MS Parma, Biblioteca Palatina 1227, transmits them as an independent short treatise on fiefs and homage - a Tractatus super feudis et homagiis. In 1906, Jean Acher was misled by the unknown compiler of this only witness and edited this Tractatus as a self-standing work. Acher had noticed some issues concerning the reliability of this compiler, but he did not realise the extent of his manipulations on the texts contained in the code. Several tracts are misattributed, and nearly all contain deceptive interpolations. ${ }^{57}$ Blanot's text, in particular, though rightly attributed to the Burgundian author, was not only misleadingly reported as a self-standing tract, with no connection to the broader treatise De actionibus of which it was an extract; it was also interpolated with several additions and citations from the Libri feudorum that were in fact not present in the original text of Blanot's De actionibus. ${ }^{58}$ Therefore, the reliance of Blanot on the Libri is much less significant than historians have thought in the past. This is very important, since the treatise De actionibus was most likely written in Italy in the mid-thirteenth century, i.e. when the Bolognese scholars were well acquainted with the Libri and the glossae apparatus was near completion, if not already completed. Notwithstanding this, Blanot developed his arguments on feudal homage - i.e. homage which entails the grant of

55 Acher, 'Notes', 161-4; J. Richard, 'Les exemples bourguignons dans le traité des hommage et des fiefs de Jean de Blanot', Mémoires de la Société pour l'Histoire du Droit et des Institutions des anciens pays bourguignons, comtois et romands, 18 (1956), 107-12.

56 Richard, 'Les exemples'; remarks shared by Giordanengo, 'Jean Blanc', 76 n. 29; Reynolds, Fiefs and Vassals, 281-3.

57 Acher, 'Notes'. See some remarks and bibliography in A. Stella, 'The Summa Feudorum of MS Parma 1227: A Work by Iacobus Aurelianus?', Reti Medievali Rivista, 20(2) (2019), 271-327, at 273-5.

58 There is no critical edition of De actionibus. I have derived these conclusions from E. Conte, Servi medievali. Dinamiche del diritto comune (Rome, 1996), 230-4, and from two manuscripts: Sion, Archives et Bibliothèque Cantonales (ABC), S. 102; Paris, Bibliothèque Nationale de France, Lat. 4106. 
a fief (homagium ratione feudi) - without considering the scholarly interpretations of the book that were available at the time.

The insertions by our unknown interpolator correspond mostly with arguments that Blanot built considering the customs held in some places' ('in aliquibus locis'), 'parts' (partes), 'regions' (regiones) or even the entirety of France ('per vulgare Francie'). This positioning suggests that our unknown interpolator was interested in highlighting the divergences between the local customs of France and the Libri. The contrast between the two, however, was implicitly subsumed in nearly all of Blanot's treatment of homage and fiefs. This contrast emerges very clearly in the argument concerning the heritability of the feudal bond, in which Blanot asked whether succession into fiefs was like other kinds of succession. His answer was negative, because neither women nor monks nor the maimed could succeed into fiefs, and this was 'according to the custom approved by Lord Frederick I, as it is contained in the constitution concerning the usages of fiefs' - this is as far as Blanot went in mentioning the Libri, without citing any specific chapter of the book. ${ }^{59}$ However, he went on to say that in some regions the custom was ('in aliquibus locis est consuetudo') that women, agnates, cognates, and even non-relatives may succeed in the absence of closer relatives. ${ }^{60}$ In another passage, he questioned the principle of egalitarian inheritance in fiefs that underpinned most of the Libri, this time not even mentioning the book, by expounding a 'statement of custom' ('declaratio consuetudinis'):

in many places, it is observed by custom that if someone is my man and holds all his property in fief from me, his firstborn takes an oath of fidelity to me and is bound to serve me against my enemies, for ... it is rightful to choose one [heir], and custom chooses the firstborn ... The same way custom burdens the firstborn on the one hand, so on the other one it benefits him because his younger brothers are bound to do homage and take an oath of fidelity to him ... and this is the custom in the regions beyond the Alps. ${ }^{61}$

Custom - and in no way the Libri - governs succession in fiefs. The authority of local custom was then restated in the description of the

59 Sion, ABC, 102, fo. 20rb: 'non, quia nec mulier, nec monachus, nec mancus succedit in feudum, secundum consuetudinem approbatam per dominum Fredericum seniorem, ut in const(itutione) de usibus feudorum continetur.' The unknown interpolator at this point cites eight chapters of the Libri: LF 1.8.2, 1.4, 2.11, 2.17, 2.50, 2.21, 2.26.6, 2.30.

60 Sion, ABC, 102, fo. 20rb.

${ }^{61}$ Acher, 'Notes', 156-7. 
nature of the feudal contract. The point of departure was the acknowledgement that if not even death could free a man from the obligations of homage - since his heirs would inherit them - the waiver of the fief would in no way suffice to exempt the vassal from such obligations. Blanot first discarded the opinion held by 'some people' ('ut voluerunt quidam dicere') according to which the feudal contract was 'innominate', i.e. a contract which does not conform to a standard set by law and which parties create ad hoc based on specific needs. More specifically, Blanot challenged the idea that the feudal contract was of the kind 'do ut facias', a service contract by which someone gives something in exchange for a performance. He found a more fitting analogy with other 'nominate' contracts founded in Roman law, such as emphyteusis, according to which withdrawal was not allowed after the closing (D. 12.4.16, C. 4.10.5, C. 4.66.1) - a good analogy with the impossibility of a vassal withdrawing from feudal obligations. However, since the feudal contract did not rest on written law, Blanot went on to suggest that even though it was derived from custom ('inductus de consuetudine'), it was nonetheless 'nominate': it conformed to a standard. This standard was provided by the binding force of custom, which, as Blanot asserted throughout the tract, was an unwritten tradition substantially diverging from the content of the Libri. ${ }^{62}$

\section{The Feudal Contract and Customary Law according to Aurelianus}

The notions on which Blanot rested his arguments on custom are strikingly similar to the ones utilised by another French lawyer active in the mid-thirteenth century: Iacobus de Aurelianis, or Aurelianus (Jacques d'Orleans). He was the author of some glossae and additiones to the Libri feudorum and possibly the compiler of an alternative version of the Libri, known as the Liber domini Iacobi de Aurelianis. In a recent essay, I suggested that Aurelianus was the author of the mysterious Summa feudorum transmitted by MS Parma 1227, the authorship of which has been the object of several speculations. ${ }^{63}$ This Summa is an unfinished work, the definitive version of which is unfortunately lost.

62 Ibid., 149 and 171. On later interpretations of this definition, see A. Massironi, Nell'officina dell'interprete. La qualificazione del contratto nel diritto comune (secoli XIV-XVI) (Milan, 2012), 312 n. 44.

63 Stella, 'The Summa Feudorum', 272-85, with an updated edition of the Summa at 287-327. 
Like Blanc's Epitome, it is a commentary upon the Libri feudorum, written in the wake of the Italian tradition. While it has been seen as a practice-oriented treatise, there is scarcely a mention of specific cases and usages. ${ }^{64}$ Nonetheless, even if Aurelianus moved more comfortably than Blanot within the maze of Canon law sources and his pattern of reasoning denoted much stronger influences of the liberal arts, this Summa presents several points of convergence with the work of the Burgundian lawyer.

In particular, the two authors seem to share the same ideas about primogeniture and the nature of the feudal contract. ${ }^{65}$ Concerning the former, we have seen that in his 'statement of custom' Blanot suggested that the consuetudo of the regions beyond the Alps ('partes ultramontanas') was to choose the firstborn ('consuetudo eligit primogenitum'). Aurelianus suggested that by the custom of 'our regions' ('in partibus nostris'), the lord chooses the firstborn urged by the necessity of custom ('dominus primogenitum eligit necessitate consuetudinis suadente'). ${ }^{66}$ The idea is the same and is expounded through a strikingly similar vocabulary. What is more, precisely like Blanot, Aurelianus thought of the feudal contract as a nominate contract founded in custom ('contractus nominatus consuetudine inventus'). In his Summa, however, the argument is much more sophisticated than in Blanot's tract. Aurelianus developed it very carefully, weighing all the elements, in a skilful application of logic to legal reasoning. ${ }^{67} \mathrm{He}$ first reported two different opinions: some authors say that the feudal contract is a service contract ('do ut facias') which is 'innominate' and thus with no foundation in Civil law; some others, including Roffredus, hold that it is a donatio sub modo, a donation given on determined conditions, hence a nominate contract, the substance and form of which was provided by Roman law. From the synthesis of these two elements, Aurelianus suggests the emergence of a third one:

${ }^{64}$ E. Cortese, 'Scienza di giudici, scienza di professori tra XII e XIII secolo', in E. Cortese, Scritti, ed. I. Birocchi, 2 vols. (Spoleto, 1999), vol. I, 93-148, at 143-4.

${ }^{65}$ It seems possible that Aurelianus knew Blanot's work - one might even wonder if he attended Blanot's lectures in Bologna. The attendance of French students at Blanot's Bolognese lectures would explain Blanot's choice to clarify legal arguments in light of customs and examples from Burgundy and France. One of the main problems, nonetheless, is that Aurelianus was keen on mentioning very explicitly the authors on whom he relied, but he did not cite Blanot at all.

66 Stella, 'The Summa Feudorum', 290, at lines 107-13.

67 Ibid., 297-8, at lines 375-424. 
I say that it is a contract in itself which has something of the aforementioned service contract and something of the donatio sub modo. Hence a tertium quid is obtained which possesses its own nature, conception, and definition ... I say that if we consider its form, this is a nominate contract founded in custom, but if we consider its matter, it took its origin from the ius gentium (see the argument as in D. 43.26 .1 and 43.26.14). ${ }^{68}$

Resorting to the notions of matter and form (materia and forma), he asserts that the substantial existence of the feudal contract could derive its form only from customary law. He cites the Libri feudorum (LF 2.32), where it is said that the 'solemnity of custom', i.e. right customary procedure, is needed to consider a feudal grant to be valid. On this specific point, Aurelianus did not use the book to provide a statement of custom but as a source to prove the vital function of custom in shaping the feudal contract. This is even clearer from the following step of the argument, in which Aurelianus compared this contract with verbal agreements, such as stipulatio and acceptilatio, and with serfdom. By their substance, they all originally belonged to the ius gentium, i.e. the composite body of unwritten laws and principles which, according to Roman law, were innate and common to all peoples (D. 1.1.1.5, 1.1.5). These analogies led the argument to its finale: since 'the form gives existence to the substance' ('forma dat esse rei'), a maxim possibly borrowed from Peter of Spain's treatise on logic, Aurelianus concluded 'daringly that it must be held that the feudal contract is a nominate contract founded in custom, for it takes its existence (esse suum) from custom'. ${ }^{69}$ The bottom line is that the verbal agreements between lords and vassals would be no 'contract' were it not for the crystallisation granted by custom. Interestingly, the Libri entered this argument as an authoritative source to prove that certain formalised practices and rituals were needed for the feudal contract to subsist. However, the ius consuetudinarium that provided these agreements with a nomen was not the text of the Libri feudorum, which, as the author admitted, is most disorganised and averts me, and perhaps many others, from the way of truth' ${ }^{70}$ The form, and hence the existence of the feudal contract, could only be provided by unwritten custom.

68 Ibid., 298, at lines 398-401.

69 Petrus Hispanus, Summule logicales, ed. L. M. de Rijk (Leiden, 1972), 68; Stella, 'The Summa Feudorum', 299, at lines 420-424.

70 Stella, 'The Summa Feudorum', 278. 


\section{Feudal Law and the Making of the ius commune}

This initial contribution to the study of the geographical dimensions of feudal law, its interrelations with local custom and its long-standing yet unsettled dialectics with the Libri feudorum has been suggestive from several points of view. In the first place, the three examples we have observed attest to very different approaches to the relationship between custom and the Libri. Blanc and Aurelianus took it as a reference book but did not share the same view on its nature and function. Blanc seems to have pursued a project of expansion of the boundaries set by the Libri, accepting both its normative potential and its authority as a source for legal arguments. Aurelianus, on his part, did not spare criticism of the Libri, but he nonetheless decided to dedicate a treatise to it. Although he did not question its utility as a text to drive doctrinal debate on fiefs, he shared Blanot's mistrusting attitude towards its normative value and its applicability to non-Italian contexts. Coming to Blanot, further analysis is needed to clarify his actual reliance on the Libri. Nonetheless, he certainly believed that the book was not an appropriate tool for describing homage and the feudal bond to a Burgundian or French audience. This sentiment, we know, was shared by generations of later French scholars, even those who cited and commented upon the Libri. The roots of the sixteenth-century debate on the authority and normativity of the book in the French contexts thus originated at the very first encounter of French scholars with it.

In the second place, the reliance of the norms regulating fiefs and homage on local usages compelled lawyers to take a clear stance on the matter of custom. The survival of unwritten legal traditions and the fact that 'learned' lawyers were ready to receive them and combine them within more or less structured theories of 'authority' and 'normativity' would suggest some continuity, if not circularity, between the two spheres of social practice and legal doctrine. Such circularity narrows significantly the alleged gap dividing 'warm natural custom' from 'cold artificial law', a gap that, as we have seen, underpins several historical paradigms of legal and institutional change in twelfth-and thirteenth-century Western Europe. In particular, this circularity questions the very idea that 'learned law' should be seen just as a product of the professionalisation, or bureaucratisation, of the legal profession, and casts doubts on the foundations on which models of the twelfth- and thirteenth-century 'transition' rely.

Ultimately, by pointing at the geographical dimensions of these doctrinal debates and their relationship with local and unwritten customs, 
our examples provide a vantage point to observe some underestimated processes at work in the making of the ius commune. Legal historians have often tended to stress uniformity and unity in explaining its emergence. $^{71}$ Feudal law and its absorption within the system of the ius commune offer a slightly different perspective, telling us a story in which local legal traditions not only survived but remained a constitutive element of the Western European experiences of law.

${ }^{71}$ Bellomo, The Common Legal Past; P. Grossi, A History of European Law (Chichester, 2010), 24-38. 